\title{
Occurrence of Race 3 of Phytophthora nicotianae in North Carolina, the Causal Agent of Black Shank of Tobacco
}

\author{
C. A. Gallup and H. D. Shew, Department of Plant Pathology, Campus Box 7903, North Carolina State University, \\ Raleigh, NC 27695
}

\begin{abstract}
Gallup, C. A., and Shew, H. D. 2010. Occurrence of race 3 of Phytophthora nicotianae in North Carolina, the causal agent of black shank of tobacco. Plant Dis. 94:557-562.
\end{abstract}

Black shank, caused by the oomycete Phytophthora nicotianae, causes significant annual yield losses in tobacco. Race 3 of P. nicotianae is reported here for the first time from North Carolina. It was identified from a North Carolina tobacco field with a history of tobacco varieties with $P h l$ gene resistance and numerous field sites with no known deployment of varieties with the Phl gene. Race 3 was originally described from cigar-wrapper tobacco in Connecticut in the 1970s, but has not been reported in any other location since. Race 3 was defined as overcoming the Phl gene from Nicotiana longiflora but not the Php gene from N. plumbaginifolia. Stem and root inoculations were conducted on a set of host differentials to determine the virulence of North Carolina isolates. Stem inoculation was unable to distinguish between races 0 and 3 of $P$. nicotianae and is not a reliable method of identifying these virulence types. Race 1 gave a unique phenotype using stem inoculation. Root inoculation was the only reliable means of distinguishing between races 0 and 3. This is the first report of race 3 in North Carolina and the first report of damage to seedlings from root inoculations and to plants containing the $P h l$ gene in naturally infested soil.

Black shank of tobacco (Nicotiana tabacum), caused by the oomycete Phytophthora nicotianae (van Breda de Haan), occurs in most tobacco-producing regions worldwide $(17,27,28)$. In North Carolina, annual losses to the disease have averaged over \$10 million since 1995 (21). Black shank of tobacco is primarily a root rot disease, but also causes severe aboveground symptoms characterized by black stem necrosis at and above the soil line, overall wilting and chlorosis, and plant death $(9,17,27)$.

Planting resistant varieties is the most effective means of suppressing black shank disease pressure. Two types of host resistance are currently available to growers. Fla 301 resistance (33) is regulated by multiple genes and confers low to high levels of partial resistance against all races of $P$. nicotianae $(3,13,14,26,27,36)$. Continuous exposure to high levels of this source of resistance has been associated with increased aggressiveness in pathogen populations $(8,30)$. Complete resistance, regulated by single genes, is also available

Corresponding author: C. A. Gallup

E-mail: cagallup@dow.com

* The $\boldsymbol{e}$-Xtra logo stands for "electronic extra" and indicates that Figures 1 and 2 appear in color in the online edition.

Accepted for publication 6 January 2010.

doi:10.1094/PDIS-94-5-0557

(C) 2010 The American Phytopathological Society in commercial tobacco varieties. The $P h p$ gene from $N$. plumbaginifolia has been utilized primarily in flue-cured tobacco, but has recently been incorporated into burley varieties $(22,23)$. The $P h l$ gene from $N$. longiflora has been used only in burley tobacco $(4,12)$. Both genes confer complete resistance to race 0 and no resistance to race 1 of the black shank pathogen.

In the early 1960s, Chaplin successfully transferred the Php gene from N. plumbaginifolia to cultivated tobacco (4). The gene was not released into commercial varieties because race 1 of the pathogen was selected for in breeding nurseries before acceptable varieties could be produced (1). The breeding line NC 1071, with the Php gene but no partial resistance, was developed at this time and is now used as an indicator line for the presence of race 1 in field trials and greenhouse inoculations. The commercial flue-cured variety Coker 371-Gold, which also has a low level of Fla 301 resistance, was the first variety released to growers that contained the $P h p$ gene (12). Coker 371-Gold was not widely used by growers because of poor agronomic traits, but once the $P h p$ gene was incorporated into agronomically acceptable varieties in the 1990 s, it was widely deployed, and incidence of race 1 increased rapidly $(5,7,31)$.

In 1953, the $P h l$ gene was transferred from $N$. longiflora to a burley tobacco breeding line, L8 (34). L8, which is homozygous for the $P h l$ resistance gene, was not acceptable for commercial production because of a severe physiological leaf spot associated with the presence of this gene (34). To correct for this problem, the resistance gene is used only in a commercial hybrid that is heterozygous for the $P h l$ gene KY 14xL8. Similar to the Php gene, deployment of the $P h l$ gene also resulted in selection for race $1(16,17,29)$.

As in other crops, pathogen races are identified based on the inoculation of a set of host differentials. In the original descriptions of races 0 and 1 , isolates avirulent on $N$. plumbaginifolia (Php) were designated race 0 and virulent isolates were designated as race $1(1,2)$. In most cases, only one complete resistance gene, rather than both the $P h p$ and $P h l$ genes, was used to differentiate races 0 and 1 . Since race 1 isolates overcome both the $P h p$ and $P h l$ genes, pathogen isolates that could overcome only one of the resistance genes would have been misidentified if both resistance genes were not included in race determination tests.

To date, only races 0 and 1 have been reported in North Carolina. Race 0 is considered the wild-type and occurs in all tobacco-growing regions. Race 2 was reported in South Africa based on a differential response of three varieties, KY 14xL8, Burley 21xL8, and Delcrest 202 (35). However, since there is no known resistance gene in Delcrest 202 and race 2 has not been described elsewhere, it is not considered epidemiologically significant. Race 3 of $P$. nicotianae was reported in Connecticut by McIntyre and Taylor (20). They identified isolates from Connecticut cigar-wrapper tobacco that differed from isolates of races 0 and 1 based on steminoculations of L8 $(P h l)$ and NC 1071 (Php) plants. Their race 0 and 1 isolates gave expected results on resistant and susceptible genotypes. Connecticut isolates caused a limited stem necrosis on L8 (Phl gene) but no disease on a line that had the $P h p$ gene (19). In a more detailed study, the Connecticut race 3 isolates were differentiated from other races based primarily on physiological differences and did not differ in virulence from race 0 , except that they caused a limited stem necrosis (several centimeters from the inoculation site) on $56 \pm 4 \%$ of the L8 plants that were stem-inoculated (18). Limited stem necrosis also has been reported with race 0 isolates on varieties with the $P h l$ gene $(11,35)$. No damage from root inoculations was reported with the Connecticut race 3 isolates. Since pathogen races are defined 
by their ability to overcome single-gene resistance, and the primary differences described for this race were physiological, race 3 was not widely accepted and has not been reported elsewhere.

Since 1999, isolates of $P$. nicotianae have been recovered from North Carolina tobacco fields that do not fit descriptions of race 0 or 1 . A study conducted from 2000 through 2003 explored the effects of variety rotation on race development in field microplots (30). Some plots were infested with race 0 and were planted each year with varieties with only partial resistance. As expected, most isolates recovered at the end of this study were race 0 . However, some isolates caused disease on rootinoculated KY 14xL8 seedlings $(P h l)$ and not on NC 1071 seedlings (Php) (Fig. 1). Race 3 was described as causing limited stem necrosis on approximately $60 \%$ of stem-inoculated KY 14xL8 plants. In contrast to the original race 3 descriptions, the $\mathrm{NC}$ isolates killed root-inoculated $\mathrm{KY}$ $14 \times L 8$ plants. Since root inoculations were never conducted, and the development of stem lesions was not severe in the initial reports of race 3 , it was unclear if the isolates recovered from this infested microplot study were race 3 or a new race. Additionally, no tobacco varieties with the $P h l$ gene are planted in Connecticut, so no field losses of plants with this gene had been observed or described (18-20).

Field trials conducted in multiple North Carolina counties also yielded this race phenotype. In some plots where single-
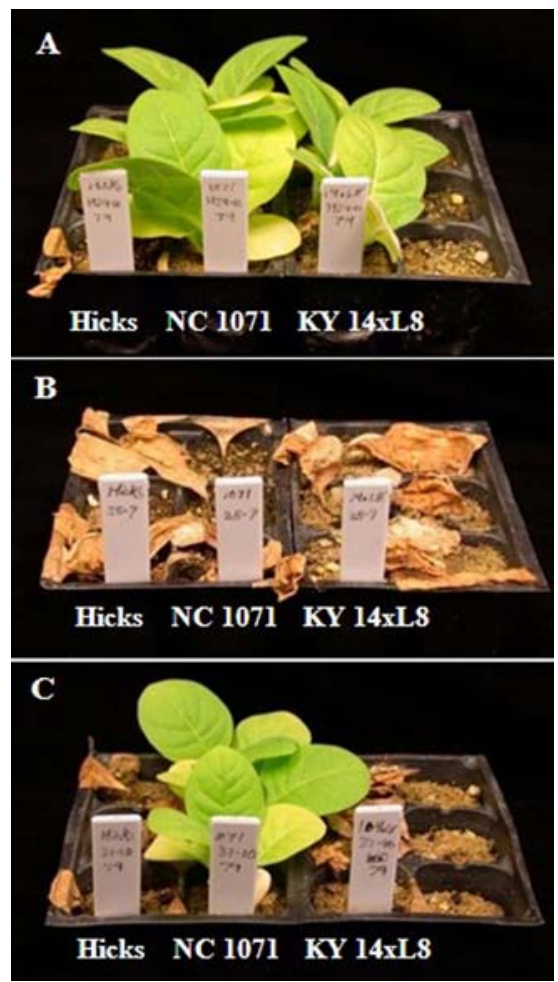

Fig. 1. Differential tobacco (Nicotiana tabacum) varieties root-inoculated with each race of Phytophthora nicotianae. A, Race 0. B, Race 1. C, Race 3. gene resistance had not been deployed previously, adult plants of KY 14xL8 (Phl) were killed, yet adjacent rows of NC 1071 (Php) were healthy (Fig. 2). Since varieties utilizing the $P h l$ and $P h p$ genes are not typically planted together in a field, disease in either of these cultivars typically is assumed to be the result of the presence of race 1 of the pathogen, and not a race specific to one of the resistance types. No reports have described the field occurrence of black shank on varieties with the $P h l$ gene and not on varieties with the $P h p$ gene. The objective of this study was to characterize the isolates from multiple locations in North Carolina that exhibited this new phenotype on a set of host differentials.

\section{MATERIALS AND METHODS}

Collection of isolates. Isolates included in the stem-inoculation study were collected over numerous locations and years (Table 1). Briefly, isolate 129 was obtained from the microplot field study conducted by M. J. Sullivan (30) and was maintained in sterile water tubes at room temperature. Isolate 97 is a race 3 isolate obtained from Connecticut in 1983 by our lab. The isolate was from cigar-wrapper tobacco and had been maintained on agar plugs in sterile water tubes at room temperature and transferred periodically to maintain viability. Prior to this study, the isolate was recovered three consecutive times from inoculated Hicks plants in an attempt to restore pathogen aggressiveness. The other isolates used in the study were obtained from tobacco fields in nine different North Carolina counties. All isolates were recovered from soil that was collected from the root zone of plants with symptoms of black shank.

Soil assays were conducted according to Sullivan et al. (30) with some modifications. To recover isolates from soil, $1 \mathrm{~g}$ of infested soil was suspended in each of three beakers containing $25 \mathrm{ml}$ of deion-

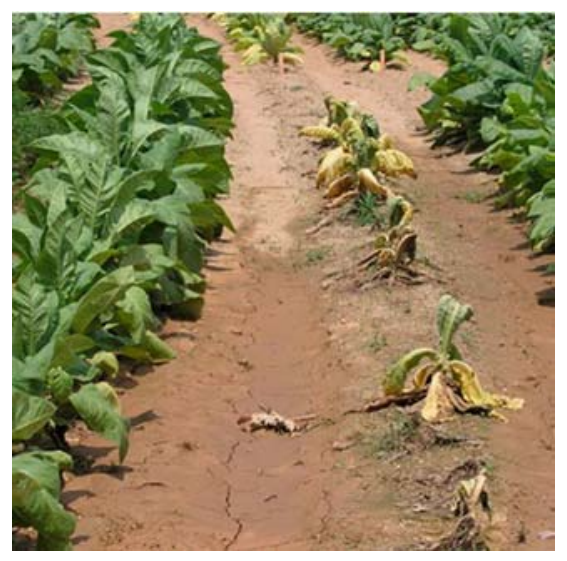

Fig. 2. North Carolina black shank field trial where burley tobacco plants of the variety KY $14 \times L 8(P h l)$ (right) were dying, yet plants of the flue-cured variety NC 71 (Php) (left) in the adjacent row were healthy. ized (DI) water. The suspension was poured in 5-ml aliquots over five plates of PARPH semiselective medium using 5\% V8 agar as the basal medium $(14,25)$. Briefly, $2 \mathrm{~g}$ of $\mathrm{CaCO}_{3}$ was suspended in $250 \mathrm{ml}$ of $\mathrm{V} 8$ juice and $750 \mathrm{ml}$ of DI water. The suspension was autoclaved at $121^{\circ} \mathrm{C}$ for $10 \mathrm{~min}$, clarified by vacuum filtration through Celite 545 (Fisher Scientific, Fair Lawn, NJ), brought to volume and autoclaved at $121^{\circ} \mathrm{C}$ for $30 \mathrm{~min}$ for two consecutive days. Broth was stored at room temperature until needed. PARPH was prepared by autoclaving $200 \mathrm{ml}$ of filtered V8 broth, $800 \mathrm{ml}$ of DI water, and $20 \mathrm{~g}$ of Bacto Agar (Difco, Detroit, MI) at $121^{\circ} \mathrm{C}$ for $30 \mathrm{~min}(5 \% \mathrm{~V} 8)$. The medium was allowed to cool to $55^{\circ} \mathrm{C}$ before adding the following chemicals and pouring: $125 \mathrm{mg}$ of pentachloronitrobenzene (PCNB), 50 $\mathrm{mg}$ of hymexazol, $250 \mathrm{mg}$ of ampicillin, 2 $\mathrm{ml}$ of rifampicin stock $(500 \mathrm{mg}$ of rifamycin SV sodium salt in $100 \mathrm{ml}$ of $95 \%$ $\mathrm{EtOH})$, and $2 \mathrm{ml}$ of pimaricin stock (500 $\mathrm{mg}$ of natamycin in $100 \mathrm{ml}$ of sterile DI water). Plates were incubated in the dark at room temperature for 2 days and then were washed with running tap water to remove the soil from the agar surface. Distinct colonies of $P$. nicotianae were transferred to a fresh plate of PARPH. Once obtained, isolates were grown on $5 \%$ clarified carrot agar (CA) (Hollywood or The Hain Celestial Group Inc., Melville, NY) (31). For this, carrot juice was filtered through Celite 545 (Fisher Scientific) and stored at $-20^{\circ} \mathrm{C}$ until needed. The CA medium was made by adding $50 \mathrm{ml}$ of the filtered carrot juice to $950 \mathrm{ml}$ of DI water and $20 \mathrm{~g}$ of Bacto Agar. The medium was autoclaved at $121^{\circ} \mathrm{C}$ for $30 \mathrm{~min}$ and allowed to cool to $55^{\circ} \mathrm{C}$ before pouring. For storage, colonized agar plugs were placed in sterile water in test tubes and maintained at room temperature.

Race determination. Root inoculation. Twelve isolates were selected for this study based on an initial race determination. Race was determined initially based on root inoculation of a set of host differentials. Genotypes consisted of varieties Hicks, with no resistance gene, the breeding line NC 1071, with only the Php gene, and KY $14 x L 8$, with only the $P h l$ gene.

Isolates were screened for race as described by Sullivan et al. $(30,31)$ except that the variety K326 was not included because it is not necessary to identify races. Briefly, 3-week-old seedlings were transplanted into cell packs ( 72 cells, $4 \times 4$ $\times 5 \mathrm{~cm})$ containing 1:1:1 ( $\mathrm{vol} / \mathrm{vol} / \mathrm{vol})$ mixture of steam pasteurized soil, potting mix, and coarse builder's sand. Inoculum was prepared by autoclaving $500 \mathrm{~cm}^{3}$ of oat grains with $300 \mathrm{ml}$ of DI water for three consecutive days at $121^{\circ} \mathrm{C}$. Sterile oat grains were poured onto the surface of pure cultures, wrapped with Parafilm, and incubated at room temperature for 7 to 10 days. Plants were inoculated by placing 
two colonized oat grains into each cell containing one 4-week-old seedling. Disease was rated 10 to 14 days after inoculation. If only seedlings of the variety Hicks were killed, then the isolate was designated as race 0 . If the seedlings of variety Hicks, the breeding line NC 1071 (Php), and the variety $\mathrm{KY} 14 \mathrm{xL} 8(\mathrm{Phl})$ were killed, the isolate was designated as race 1. If NC 1071 seedlings were asymptomatic, Hicks was killed, and KY 14xL8 was killed, then the isolate was included in the stem-inoculation study for further comparisons. The root inoculation test was repeated to confirm race designation.

Stem inoculation. In order to make comparisons consistent with the original description of race 3 and with previous studies on race determination $(6,11,20$, 35,37 ), a stem-inoculation study was conducted with multiple isolates of races 0 and 1, one isolate of race 3 (CT 97), and the set of NC isolates.

Inoculum was prepared for each isolate according to Csinos $(6,7)$ with slight modifications. Cultures of $P$. nicotianae were grown on $5 \% \mathrm{CA}$, and toothpicks were sterilized in a clarified 5\% V8 broth for 30 min prior to use. Each isolate was grown on CA medium for 7 days at room temperature, 22 to $25^{\circ} \mathrm{C}$, and then the sterile broth infused toothpicks were placed on the agar surface and incubated for 7 days in the dark at room temperature. Colonized toothpicks were removed from the agar surface and used immediately to inoculate plants.

Three tobacco varieties and a breeding line were used as host differentials: Hicks, NC 1071, KY 14xL8, and L8. Seeds of each variety were sown into flats containing potting mix (Metro Mix 200, The Scotts Company, Marysville, $\mathrm{OH}$ ) and allowed to grow for 4 weeks. After 4 weeks, the seedlings were transplanted into 10-cm (4-in.) pots containing a 1:1:1
( $\mathrm{vol} / \mathrm{vol} / \mathrm{vol}$ ) mixture of steam pasteurized $\left(80^{\circ} \mathrm{C}\right.$ for $\left.30 \mathrm{~min}\right)$ soil, potting mix, and coarse builder's sand. Plants were allowed to grow for an additional 12 weeks before inoculation. All plants were watered twice daily and fertilized every 7 days with 2020-20 Miracle-Gro (The Scotts MiracleGro Company, Marysville, OH).

Plants were inoculated by pushing a sterilized probe through the stem at approximately half the plant height. An infested toothpick was immediately inserted into the wound, and the inoculation site was wrapped with several layers of Parafilm. Wounded plants without inoculum served as controls. The experiment was arranged as a randomized complete block with five replicate plants per treatment and was conducted twice. Lesion lengths were measured using a digital caliper at 3, 5, and 7 days after inoculation. Area under the lesion expansion curve (AULEC) values for each plant were calculated using SAS (Version 9.2, SAS Institute, Cary, NC). Analysis of variance was performed on the AULEC values using the PROC MIXED procedure of SAS.

Identification of the race 3 phenotype in field populations of $P$. nicotianae. Isolates of $P$. nicotianae were collected from the soil around the root zone of symptomatic plants in field trial plots across three counties that had been maintained for multiple years by North Carolina State University. When possible, 10 isolates were collected per plot and screened for race as described above. The planting history and gene deployment were recorded for each plot (Table 2).

\section{RESULTS}

Race determination. Root inoculation. Each isolate used in this stem inoculation study initially was characterized based on root inoculation of a set of standard host differentials (Table 3). Plants were rated qualitatively, dead or living, and no quantitative measure, such as percent root rot, was assessed. In fact, no intermediate symptoms were observed on any of the seedlings; seedlings either died or showed no disease symptoms. From these initial tests, multiple isolates of races 0 and 1 were selected for comparison to the new NC isolates (Table 1).

Stem inoculation. There was a significant run effect $(P<0.001)$ in the experiment, so data from the two runs of the experiment were analyzed separately. Interactions of host genotypes and pathogen isolates were similar across runs, but levels of disease were much lower in the second run of the experiment than in run 1 .

All isolates caused disease on the susceptible variety Hicks. AULEC values were highest on Hicks for all variety $x$ isolate combinations except for the race 1 isolates on NC 1071, which is highly susceptible to race 1 (Figs. 3 and 4). All three race 1 isolates produced extensive stem lesions on all varieties as predicted from the root inoculations, averaging between 163 and $416 \mathrm{~mm}$ in length over the experiment.

Within each run, lesion expansion on Hicks was not significantly different among races 0,1 , and the North Carolina isolates. Isolate 97 , which was the only race 3 isolate available for comparisons, was much less aggressive than all other isolates and typically produced smaller stem lesions than all other isolates on all varieties in both runs of the experiment ( $P$ $=0.0001)$. The average AULEC for isolate 97 was only 56 compared to the overall average of 377 in the first run. In the second run, the average AULEC for isolate 97 was only 12 compared to the overall average of 207.7 .

Although isolate 97, the Connecticut race 3 isolate, caused very low levels of disease, the pattern of disease was very

Table 1. Isolates included in the stem inoculation study to determine the race of five Phytophthora nicotianae isolates in North Carolina

\begin{tabular}{|c|c|c|c|c|c|c|c|c|c|}
\hline \multirow[b]{3}{*}{ Isolate } & \multirow[b]{3}{*}{ Location } & \multirow[b]{3}{*}{ Year } & \multirow{2}{*}{\multicolumn{4}{|c|}{ Field history $^{a}$}} & \multicolumn{3}{|c|}{ Race $^{b}$} \\
\hline & & & & & & & \multirow{2}{*}{$\begin{array}{l}\text { Initial race } \\
\text { root inoculation }\end{array}$} & \multirow{2}{*}{$\begin{array}{c}\text { Run 1 } \\
\text { stem inoculation }\end{array}$} & \multirow{2}{*}{$\begin{array}{c}\text { Run 2 } \\
\text { stem inoculation }\end{array}$} \\
\hline & & & 2003 & 2004 & 2005 & 2006 & & & \\
\hline DT10 & Duplin Co., NC & 2006 & $\mathrm{NH}$ & 301 & $\mathrm{NH}$ & 301 & 0 & 3 & 3 \\
\hline EL2 & Edgecombe Co., NC & 2006 & 301 & $\mathrm{NH}$ & 301 & Php & 0 & 3 & 3 \\
\hline RB15 & Rockingham Co., NC & 2006 & $\mathrm{NH}$ & 301 & $\mathrm{NH}$ & Php & 0 & 3 & 3 \\
\hline DB12 & Davie Co., NC & 2006 & NH & NH & 301 & Php & 1 & 1 & 1 \\
\hline FL9 & Forsyth Co., NC & 2006 & No data & & & & 1 & 1 & 1 \\
\hline YB10 & Yadkin Co., NC & 2006 & $\mathrm{NH}$ & $\mathrm{NH}$ & 301 & Php & 1 & 1 & 1 \\
\hline $97^{c}$ & Connecticut & 1983 & & & & & 3 & 3 & 0 \\
\hline $31^{\mathrm{d}}$ & Buncombe Co., NC & 1999 & & & & & 3 & 3 & 3 \\
\hline $129^{\mathrm{e}}$ & Field study, NC & 2003 & 301 & 301 & 301 & 301 & 3 & 3 & 3 \\
\hline H109 & Hoke Co., NC & 2004 & 301 & 301 & NA & NA & 3 & 3 & 3 \\
\hline $\mathrm{SF} 2$ & Sampson Co., NC & 2006 & NH & Php & $\mathrm{NH}$ & 301 & 3 & 3 & 3 \\
\hline WP10 & Wayne Co., NC & 2006 & $\mathrm{NH}$ & $\mathrm{NH}$ & 301 & 301 & 3 & 3 & 3 \\
\hline
\end{tabular}

${ }^{\text {a }}$ History of tobacco resistance gene deployment from 2003 to 2006: Phl = single-gene resistance from N. longiflora; Php = single-gene resistance from N. plumbaginifolia $; 301=$ Fla 301 resistance; $\mathrm{NH}=$ nonhost crop.

${ }^{b}$ Races were initially defined based on root inoculations and designations were used for statistical analysis. Races were not adequately differentiated based on area under the lesion expansion curve (AULEC) for stem inoculations.

${ }^{\mathrm{c}}$ Isolate 97 was collected in 1983 from cigar-wrapper tobacco in Connecticut. Isolates collected from North Carolina were compared against this isolate.

${ }^{\mathrm{d}}$ Isolate 31 was isolated from a soil sample taken from the root zone of a KY 14xL8 plant during a survey of the burley tobacco regions for race.

${ }^{\mathrm{e}}$ Isolate 129 was obtained from a microplot field study conducted by M. J. Sullivan (30) where Fla 301 resistance was deployed over multiple years. 
similar to the North Carolina isolates. The new North Carolina isolates caused extensive necrosis on the susceptible Hicks, intermediate levels of disease on $\mathrm{KY}$ $14 \times 28$ and L8, and no necrosis on NC 1071. Isolate 97 and the new North Carolina isolates caused more extensive lesions on the variety KY $14 x L 8$, which is heterozygous for $P h l$, than on the breeding line L8, which is homozygous for the $\mathrm{Phl}$ gene (Figs. 3 and 4).

The race 0 isolates used in this study killed neither the Php nor the Phl genotypes in the initial root inoculations. However, in the stem-inoculation experiment, all three race 0 isolates caused stem lesions on KY $14 x L 8$, which is heterozygous for the $P h l$ gene, and two of the three isolates caused stem lesions on the L8 variety, which is homozygous for the $P h l$ gene. Overall, AULEC values for race 0 isolates were lower on the $P h l$ varieties than on Hicks (Figs. 3 and 4).

Identification of the race 3 phenotype in field populations of $P$. nicotianae. Isolate 31 was obtained from a burley tobacco field planted with KY 14xL8 in Buncombe County, NC (Table 1). Several other isolates with a race 3 phenotype were collected from field plots planted with KY 14xL8 (Table 2). However, many of the isolates that gave a race 3 phenotype were obtained from areas that had no record of exposure to the $P h l$ gene (Tables 1 and 2).

\section{DISCUSSION}

Isolates of $P$. nicotianae that could overcome the $P h l$ gene but not the Php gene in root inoculations were recovered from multiple tobacco fields in North Carolina. These fields included locations with and without a planting history of tobacco varieties with the Phl single-gene resistance. The only previous reports of a race that was virulent on the $P h l$ gene and avirulent on the Php gene were in the 1970s on cigar tobacco in Connecticut $(19,20)$. No subsequent reports have been made on the occurrence of this race. Pathogen races are defined based on a qualitative response of host differentials to inoculation by isolates of the pathogen that demonstrate virulence on those genotypes (24). The initial description of race 3 was based on the susceptibility of stems, but not roots, of the breeding line L8. Additional characterization of race 3 focused on multiple physiological differences compared to races 0 and $1(10,18,20)$. Since no root inoculations were conducted in the original description, and tobacco varieties grown in Connecticut do not contain the $P h l$ gene, the occurrence of race 3 was not widely accepted by tobacco pathologists. It was unclear whether the isolates collected from North Carolina were the same as those Connecticut race 3 isolates or a new race.

The North Carolina isolates were compared to the Connecticut race 3 isolate according to the original description. North
Carolina isolates were selected for this study based on a clear qualitative response of the host differentials to root inoculations. However, when isolates were inoculated into the stems of tobacco varieties, the race response was less clear. The variety NC 1071 ( $P h p$ gene) maintained the same qualitative response to stem inoculations as was observed in root inoculations; no lesions developed in response to stem inoculations with the race 0 , the Connecticut race 3 , or the North Carolina isolates, and extensive lesions developed in response to race 1 . In contrast, the two tobacco varieties with the $P h l$ gene did not respond qualitatively to stem inoculation. All isolates, regardless of the race based on root inoculations, caused stem lesions on both the KY 14xL8 (Phl heterozygous) and L8 ( $P h l$ homozygous) varieties. Therefore, isolates initially defined as race 0 based on root inoculations would be defined as race 3 based on stem inoculations.

It is likely that the susceptibility of the stems of tobacco plants with the Phl gene is due to differences in gene expression in different parts of the plant. Differential expression of resistance to $P$. nicotianae in

Table 3. Differential response of root-inoculated tobacco varieties (Nicotiana tabacum) to races of Phytophthora nicotianae

\begin{tabular}{lcccc}
\hline & \multicolumn{4}{c}{ Variety $^{\text {a }}$} \\
\cline { 2 - 5 } & Hicks & NC 1071 (Php $)$ & KY 14xL8 $(\boldsymbol{P h l}$ hetero. $)$ & L8 $($ Phl homo. $)$ \\
\hline Race 0 & + & - & - & - \\
Race 1 & + & + & + & + \\
Race 3 & + & - & + & + \\
\hline a Hicks is susceptible; NC 1071 is a flue-cured variety with the $P h p$ gene; KY 14xL8 is a hybrid burley \\
variety heterozygous for the Phl gene; L8 is a burley breeding line homozygous for the Phl gene.
\end{tabular}

Table 2. Race structure of Phytophthora nicotianae in North Carolina plots where tobacco varieties with single-gene or partial resistance were deployed over a 3-year period

\begin{tabular}{|c|c|c|c|c|c|c|c|c|}
\hline \multirow[b]{2}{*}{ Plot number } & \multirow{2}{*}{$\begin{array}{c}\text { North Carolina } \\
\text { county }\end{array}$} & \multicolumn{3}{|c|}{ Tobacco variety ${ }^{a}$} & \multirow[b]{2}{*}{ Gene deployed $^{b}$} & \multicolumn{3}{|c|}{ Race $(\%)^{\mathrm{c}}$} \\
\hline & & 2002 & 2003 & 2004 & & R-0 & R-1 & R-3 \\
\hline 1 & Franklin & Unknown & Unknown & KY 14xL8 & $P h l$ & $\ldots$ & 100 & $\ldots$ \\
\hline 2 & Franklin & Unknown & Unknown & KY 14xL8 & $P h l$ & $\ldots$ & 100 & $\ldots$ \\
\hline 3 & Franklin & Unknown & Unknown & NC 1071 & Php & $\ldots$ & 100 & $\ldots$ \\
\hline 4 & Rockingham & K 346 & K 346 & K 346 & Fla 301 & $\ldots$ & 80 & 20 \\
\hline 8 & Rockingham & SP NF3 & NC 71 & K 346 & Php / Fla 301 & $\ldots$ & 100 & $\ldots$ \\
\hline 16 & Rockingham & SP 168 & K 346 & K 346 & Php / Fla 301 & $\ldots$ & 100 & $\ldots$ \\
\hline 24 & Rockingham & SP NF3 & NC 71 & K 346 & Php / Fla 301 & $\ldots$ & 100 & $\ldots$ \\
\hline 28 & Rockingham & SP NF3 & NC 71 & K 346 & Php / Fla 301 & $\ldots$ & 100 & $\ldots$ \\
\hline 36 & Rockingham & SP 168 & K 346 & K 346 & Php / Fla 301 & 20 & 80 & $\ldots$ \\
\hline 44 & Rockingham & SP 168 & K 346 & K 346 & Php / Fla 301 & $\ldots$ & 100 & $\ldots$ \\
\hline 46 & Rockingham & SP NF3 & NC 71 & K 346 & Php / Fla 301 & $\ldots$ & 100 & $\ldots$ \\
\hline 1 & Hoke & Unknown & KY 14xL8 & Mn 944 & Php / Fla 301 & 12 & 88 & $\ldots$ \\
\hline 11 & Hoke & Unknown & K 394 & KY 14xL8 & Php / Fla 301 & $\ldots$ & 100 & $\ldots$ \\
\hline 34 & Hoke & Unknown & K 346 & $\mathrm{C} 371 \mathrm{G}$ & Php / Fla 301 & 20 & 40 & 40 \\
\hline 42 & Hoke & Unknown & K 149 & K 346 & Fla 301 & 40 & $\ldots$ & 60 \\
\hline 83 & Hoke & Unknown & SP 190 & KY 14xL8 & $P h p / P h l$ & $\ldots$ & 90 & 10 \\
\hline 97 & Hoke & Unknown & KY 14xL8 & SP 218 & Php /Phl & 50 & 20 & 30 \\
\hline 126 & Hoke & Unknown & $\mathrm{C} 371 \mathrm{G}$ & K 346 & Php / Fla 301 & $\ldots$ & 60 & 20 \\
\hline 133 & Hoke & Unknown & KY 14xL8 & GL 939 & Php / Fla 301 & 33 & 50 & 17 \\
\hline 148 & Hoke & Unknown & GL 939 & KY 14xL8 & Php / Fla 301 & $\ldots$ & 100 & $\ldots$ \\
\hline
\end{tabular}

a Variety planted from 2002 through 2004 in North Carolina field trial plots.

${ }^{\mathrm{b}}$ Source(s) of resistance to the black shank pathogen based on variety records. The Phl and Php genes are sources of complete resistance from wild tobacco Nicotiana longiflora and $N$. plumbaginifolia, respectively. Fla 301 resistance is partial resistance effective against all races of the pathogen.

${ }^{c}$ Races were determined by inoculating a set of host differentials: Hicks, susceptible; NC 1071, with the Php gene; and KY 14xL8, with the Phl gene. Race 0 killed only Hicks, race 1 killed all genotypes, and race 3 killed only Hicks and KY 14xL8. 
different tobacco tissues has been reported for other sources of resistance $(6,17)$. Quantitative resistance from Fla 301 is expressed only in the roots, so stem inoculation is not a reliable technique to discriminate between levels of partial resistance based on this resistance source $(6,17)$. In contrast, resistance conditioned by the Php gene is expressed in the stem and root tissues (6), and stem inoculation is a reliable method to determine if the isolate is race 1 .
A previous study demonstrated that the leaves of KY $14 \times L 8$ are very susceptible to $P$. nicotianae when inoculated with race 0 isolates. The level of susceptibility in the leaves was comparable to the susceptibility of varieties KY 14 and B 21, both of which lack any resistance to $P$. nicotianae (32). $P h l$ gene expression in the stem has not been assessed directly, but Apple (2) also observed that the response of steminoculated L8 plants to race 0 was variable. Breeders have long recognized this single-gene source of resistance as a qualitative type of root resistance to the black shank pathogen $(15,29)$. If resistance is completely expressed in the roots and not expressed in the leaves, it is possible that the stems express resistance at some intermediate level.

Based on this work, it is clear that root inoculations are capable of separating isolate pathogenicity to a finer level than stem inoculations. Race 1 can be identified from stem inoculations because qualitative

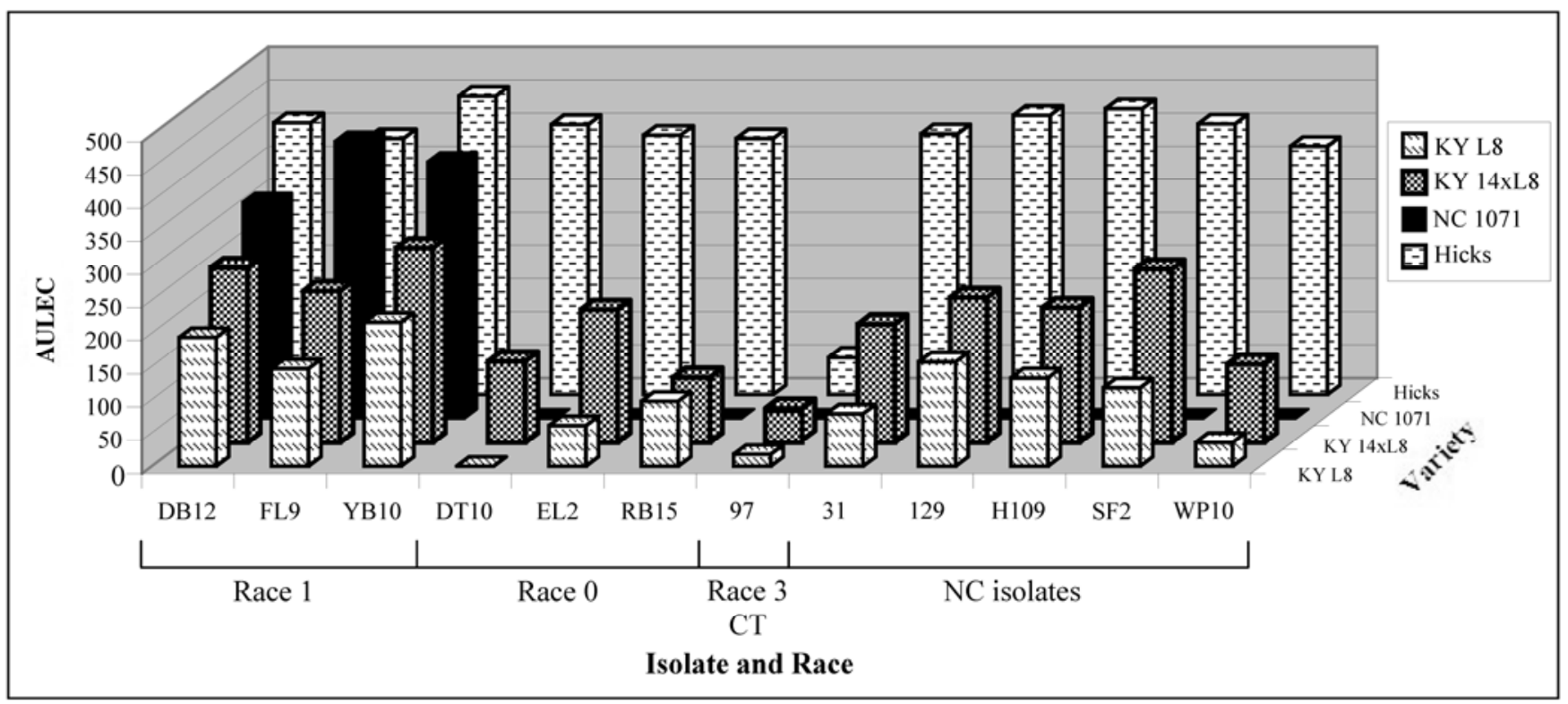

Fig. 3. Run 1. Area under the lesion expansion curve (AULEC) comparing lesions resulting from stem inoculations with Phytophthora nicotianae isolates of known races 0, 1, and 3, to isolates collected from North Carolina tobacco fields. Tobacco varieties L8 (homozygous Phl), KY 14xL8 (heterozygous Phl), NC 1071 (Php), and Hicks (susceptible) were stem-inoculated with colonized toothpicks. Races are based on a priori root inoculations using a set of host differentials: Hicks, susceptible; NC 1071, with the Php gene; KY 14xL8, with the Phl gene. Race 0 killed only Hicks, race 1 killed all genotypes, and race 3 killed only Hicks and KY 14xL8.

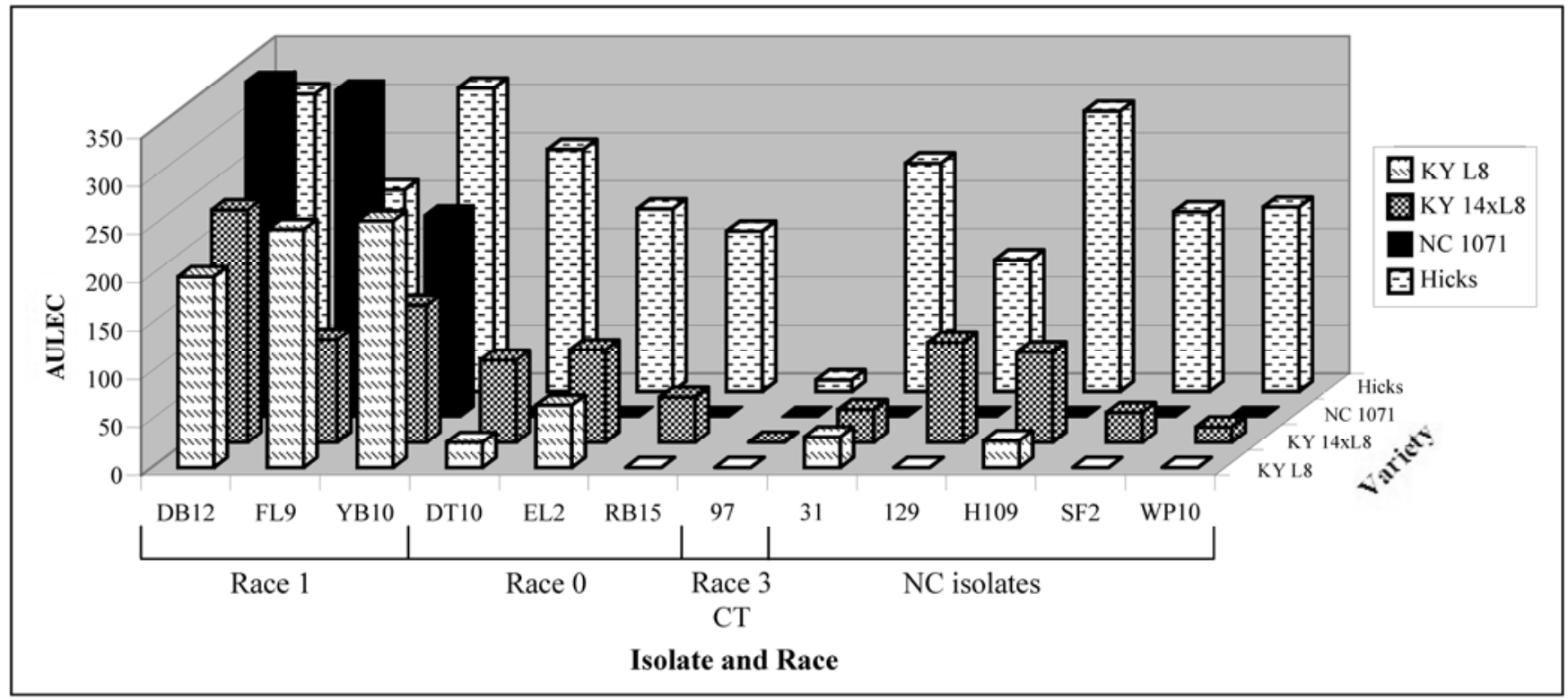

Fig. 4. Run 2. Area under the lesion expansion curve (AULEC) comparing lesions resulting from stem inoculations with Phytophthora nicotianae isolates of known races 0,1, and 3, to isolates collected from North Carolina tobacco fields. Tobacco varieties L8 (homozygous Phl), KY 14xL8 (heterozygous Phl), NC 1071 (Php), and Hicks (susceptible) were stem-inoculated with colonized toothpicks. Races are based on a priori root inoculations using a set of host differentials: Hicks, susceptible; NC 1071, with the Php gene; KY 14xL8, with the Phl gene. Race 0 killed only Hicks, race 1 killed all genotypes, and race 3 killed only Hicks and KY 14xL8. 
resistance from the Php gene in NC 1071 is completely expressed in the stems as well as the roots. However, varieties with the $P h l$ gene cannot differentiate races 0 and 3 based on stem inoculation.

This investigation suggests the occurrence of the race 3 phenotype of $P$. nicotianae as virulent on the $P h l$ gene but not the Php gene based on root inoculations where both genes result in clear qualitative reactions. With this definition, the North Carolina isolates used in this study were identified as race 3 . Race 3 isolates were recovered from multiple locations throughout North Carolina. Race 3 was recovered not only from the soil in fields where KY 14xL8 had been planted, but also from fields that had no history of the $P h l$ gene. Race 3 was also recovered from field trial plots infested with race 0 and planted only with Fla 301 resistance. In both the tobacco fields and trial plots, fully mature tobacco plants displayed typical black shank symptoms. Subsequent sampling from these plots yielded isolates that gave clear qualitative reactions on varieties with the Phl (disease) and the Php (no disease) genes.

This research demonstrated that a new differential virulence occurs in populations of $P$. nicotianae in North Carolina, similar to race 3 isolates previously described in Connecticut. Based on the original description of race 3 , these results confirm the existence of race 3 in North Carolina using field observations and root inoculations. This research also demonstrated the value of root inoculations in qualitatively separating these race phenotypes, and that stem inoculations are not conclusive for separating all races of this important plant pathogen.

\section{ACKNOWLEDGMENTS}

The authors thank K. R. Lannon for her technical assistance. This research was supported by grants from the Tobacco Research Commission, the North Carolina Tobacco Foundation, Inc., and a grant from the Tobacco Trust Fund of North Carolina.

\section{LITERATURE CITED}

1. Apple, J. L. 1962. Physiological specialization within Phytophthora nicotianae var. nicotianae. Phytopathology 52:351-354.

2. Apple, J. L. 1967. Occurrence of race 1 of Phytophthora parasitica var. nicotianae in North Carolina and its implications in breeding for disease resistance. Tob. Sci. 11:79-83.

3. Carlson, S. R., Wolff, M. F., Shew, H. D., and Wernsman, E. A. 1997. Inheritance of resistance to race 0 of Phytophthora parasitica var. nicotianae from the flue-cured tobacco cultivar
Coker 371-Gold. Plant Dis. 81:1269-1274.

4. Chaplin, J. F. 1962. Transfer of black shank resistance from Nicotiana plumbaginifolia to flue-cured N. tabacum. Tob. Sci. 6:184-189.

5. Csinos, A. S. 1994. Distribution of Phytophthora parasitica var. nicotianae races and their sensitivity to metalaxyl in Georgia. Plant Dis. 78:471-474.

6. Csinos, A. S. 1999. Stem and root resistance to tobacco black shank. Plant Dis. 83:777-780.

7. Csinos, A. S. 2005. Relationship of isolate origin to pathogenicity of race 0 and 1 of Phytophthora parasitica var. nicotianae on tobacco cultivars. Plant Dis. 89:332-337.

8. Dukes, P. D., and Apple, J. L. 1961. Influence of host passage on virulence of Phytophthora parasitica var. nicotianae. Plant Dis. Rep. 45:362-365.

9. Gallup, C. A., Sullivan, M. J., and Shew, H. D. 2006. Black Shank of Tobacco. The Plant Health Instructor. DOI: 10.1094/PHI-I-20060717-01.

10. Hankin, L., and McIntyre, J. L. 1980. Hydrolytic and transferase activities of invertases from physiological races of Phytophthora parasitica var. nicotianae. Mycologia 72:749758.

11. Hendrix, J. W., and Apple, J. L. 1967. Stem resistance to Phytophthora parasitica var. nicotianae in tobacco derived from $N$. longiflora and $N$. plumbaginifolia. Tob. Sci. 11:148-150.

12. Johnson, E. S., Wolff, M. F., Wernsman, E. A., Atchley, W. R., and Shew, H. D. 2002. Origin of the black shank resistance gene, $P h$, in tobacco cultivar Coker 371-Gold. Plant Dis. 86:1080-1084

13. Jones, K. J., and Shew, H. D. 1995. Early season root production and zoospore infection of varieties of flue-cured tobacco that differ in level of partial resistance to Phytophthora parasitica var. nicotianae. Plant Soil 172:5561.

14. Kannwischer, M. E., and Mitchell, D. J. 1978. The influence of a fungicide on the epidemiology of black shank of tobacco. Phytopathology 68:1760-1765.

15. Litton, C. C., Collins, G. B., and Legg, P. D. 1970. Reaction of Nicotiana tabacum and other $N$. species to race 0 and 1 of Phytophthora parasitica var. nicotianae. Tob. Sci. 14:128-130.

16. Litton, C. C., Stokes, G. W., and Smiley, J. H. 1966. Occurrence of race 1 of Phytophthora parasitica var. nicotianae. Tob. Sci. 10:73-74.

17. Lucas, G. B. 1975. Diseases of Tobacco, 3rd ed. Biological Consulting Associates, Raleigh, NC.

18. McIntyre, J. L., and Hankin, L. 1977. Lack of kestose (fructosyslsucrose) production by race 3 of Phytophthora parasitica var. nicotianae differentiates it from races 0 and 1 . Mycologia 69:756-760.

19. McIntyre, J. L., and Taylor, G. S. 1976. Screening tobacco seedlings for resistance to Phytophthora parasitica var. nicotianae. Phytopathology 66:70-73.

20. McIntyre, J. L., and Taylor, G. S. 1978. Race 3 of Phytophthora parasitica var. nicotianae. Phytopathology 68:35-38.

21. Mila, A., and Radcliff, J. 2008. Managing
Diseases. Pages 140 to 174 in: Tobacco Information 2009. NC Coop. Ext. Serv., Bull. AG187 (revised).

22. North Carolina Cooperative Extension Service. 2009. Burley Tobacco Guide 2009 AG-376 (revised). North Carolina State University, Raleigh

23. North Carolina Cooperative Extension Service. 2009. Flue-Cured Tobacco Guide 2009 AG187 (revised). North Carolina State University, Raleigh.

24. Plant Pathology. Concepts and Laboratory Exercises, 2nd ed. 2008. R. N. Trigiano, M. T. Windham, and A. S. Windham, eds. CRC Press/Taylor and Francis Group, Boca Raton, Fl. p. 558.

25. Shew, H. D. 1983. Effects of soil matric potential on infection of tobacco by Phytophthora parasitica var. nicotianae. Phytopathology 73:1160-1163.

26. Shew, H. D. 1985. Response of Phytophthora parasitica var. nicotianae to metalaxyl exposure. Plant Dis. 69:559-562.

27. Shew, H. D., and Lucas, G. B., eds. 1991. Compendium of Tobacco Diseases. American Phytopathological Society, St. Paul, MN.

28. Shoemaker, P. B., and Shew, H. D. 1999. Major tobacco diseases: Fungal and bacterial diseases. Pages 183-197 in: Tobacco: Production, Chemistry and Technology. D. L. Davis and M. T. Nielsen, eds. Blackwell Science, Oxford

29. Stokes, G. W., and Litton, C. C. 1966. Source of black shank resistance in tobacco and host reaction to races 0 and 1 of Phytophthora parasitica var. nicotianae. Phytopathology 56:678-680.

30. Sullivan, M. J., Melton, T. A., and Shew, H. D. 2005. Fitness of races 0 and 1 of Phytophthora parasitica var. nicotianae. Plant Dis. 89:12201228

31. Sullivan, M. J., Melton, T. A., and Shew, H. D. 2005. Managing the race structure of $P h y$ tophthora parasitica var. nicotianae with cultivar rotation. Plant Dis. 89:1285-1294.

32. Tedford, E. C. 1990. A detached-leaf technique for detecting resistance to Phytophthora parasitica var. nicotianae in tobacco. Plant Dis. 74:313-316

33. Tisdale, W. B. 1931. Development of cigar wrapper tobacco resistance to black shank (Phytophthora nicotianae Breda de Haan) Univ. Fla. Agric. Exp. Stn. Tech. Bull. 226.

34. Valleau, W. D., Stokes, G. W., and Johnson, E. M. 1960. Nine years' experience with the Nicotiana longiflora factor for resistance to Phytophthora parasitica var. nicotianae in the control of black shank. Tob. Sci. 4:92-94.

35. van Jaarsveld, E., Wingfield, M. J., and Drenth, A. 2002. Evaluation of tobacco varieties for resistance to races of Phytophthora nicotianae in South Africa. J. Phytopathol. 150:456-462.

36. Wernsman, E. A., Matzinger, D. F., and Powell, N. T. 1974. Genetic investigations of intraspecific and interspecific sources of black shank resistance in tobacco. Tob. Sci. 18:15-18.

37. Wills, W. H., and Moore, L. D. 1971. Response of some cultivars and lines of tobacco to stem inoculation with Phytophthora parasitica var. nicotianae. Tob. Sci. 15:51-53. 